Chirurgia (2018) 113: 625-633

No. 5, September - October

Copyright $@$ Celsius

http://dx.doi.org/10.21614/chirurgia.113.5.625

\title{
Current Surgical Approach in the Pathology of the Arteriopathic Predominant Diabetic Foot
}

\author{
Florin Bobircă', Anca Bobircă², Anca Bordianu ${ }^{3}$, Cristina Jauca ${ }^{4}$, Dragoș Georgescu', Raluca Radu', Traian Pătrașcu' \\ 1"I. Juvara" Surgery Clinic, "Dr. Ion Cantacuzino" Clinical Hospital, "Carol Davila” University of Medicine and Pharmacy, Bucharest, Romania \\ 2Internal Medicine Clinic, "Dr. Ion Cantacuzino" Clinical Hospital, "Carol Davila” University of Medicine and Pharmacy, Bucharest, Romania \\ ${ }^{3}$ Plastic and Reconstructive Department, "Bagdasar-Arseni" Emergency Hospital, "Carol Davila" University of Medicine and Pharmacy, \\ Bucharest, Romania \\ 4”I. Juvara" Surgery Clinic, "Dr. Ion Cantacuzino" Clinical Hospital, Bucharest, Romania \\ ${ }^{5}$ Centre for Diabetes, Nutrition and Metabolic Diseases, "N. Malaxa" Clinical Hospital, "Carol Davila" University of Medicine and Pharmacy, \\ Bucharest, Romania
}

Corresponding author: Dragos Georgescu, MD

"I. Juvara" Surgery Clinic

"Dr. Ion Cantacuzino" Clinical Hospital

5-7 Ion Movila Street, Bucharest, RO

E-mail:gfdragos@yahoo.com
Received: 09.07.2018

Accepted: 07.09.2018

\section{Rezumat}

Abordarea chirurgicală actuală în patologia piciorului diabetic predominant arteriopat

Introducere: Piciorul diabetic este o entitate patologică complexă caracterizată prin totalitatea modificărilor care apar la nivelul piciorului în timpul evolutiei bolii diabetice. Acest studiu vizează elaborarea unui algoritm de tratament pentru pacienții cu leziuni predominant arteriopate ale piciorului diabetic, cu scopul de a reduce numărul de intervenții debilitante şi de a îmbunătăți calitatea vieții.

Material şi Metodă: Au fost analizati un număr de 188 de pacienți internati la Clinica de Chirurgie I a Spitalului Clinic Dr. I. Cantacuzino, în anul 2017, cu leziuni ale piciorului diabetic predominant arteriopat, pe baza mai multor criterii de includere / excludere.

Rezultate: In functie de tipul de leziune a piciorului, majoritatea pacientilor au avut diagnosticul de gangrenă umedă a degetului / degetelor (51,06\%), urmată de gangrena ischemică a degetului / degetelor (40,4\%), intervențile chirurgicale efectuate asupra acestor tipuri de leziuni $73,9 \%$ dintre cazuri au constat din amputații minore (amputația transmetatarsiană a piciorului/a degetelor).

Concluzii: Algoritmul de tratament dezvoltat ca rezultat al acestui studiu reprezintă o soluție fezabilă de tratament pentru patologia 
piciorului diabetic predominant arteriopat, iar nerespectarea acestuia poate duce la erori de tratament în sensul în care o operație disproporționată poate fi efectuată în corelație cu un diagnostic inexact.

Cuvinte cheie: diabet zaharat, picior diabetic, gangrenă, arteriopatie, amputație

\begin{abstract}
Introduction: The diabetic foot is a complex pathologic entity characterized by the totality of modifications appearing on the foot during the evolution of the diabetic disease. This survey aims to elaborate an algorithm of treatment for patients with arteriopathic predominant diabetic foot lesions, with the purpose of reducing the number of debilitating interventions and improving the quality of life.

Material and Method: There were analysed a number of 188 patients admitted to the Surgery Clinic I of the Dr.I.Cantacuzino Clinical Hospital, in the year 2017, suffering from arteriopathic predominant diabetic foot lesions, based on several inclusion/exclusion criteria.

Results: According to the type of foot lesion, most patients had the diagnosis of wet gangrene of the toe/toes $(51.06 \%)$, followed by ischaemic gangrene of the toe/toes (40.4\%); the surgical interventions performed on these types of lesions in $73.9 \%$ of the cases consisted of minor amputations (transmetatarsal amputation of the toe/toes/foot).

Conclusions: The treatment algorithm developed as a result of this survey represents a feasible treatment solution for the pathology of the arteriopathic predominant diabetic foot and failure to comply with this treatment may lead to treatment errors in a sense in which disproportional surgery can be performed in correlation with an inexact diagnosis.
\end{abstract}

Key words: diabetes mellitus, diabetic foot, gangrene, arteriopathy, amputation

\section{Introduction}

The treatment of the diabetic foot lesions represents a topical issue, due to the continuous increase in the number of patients suffering from diabetes mellitus, approximately 425 million in the year 2017worldwide, according to the International Diabetes Federation, but also due to the potentially vital complications that these lesions are able to generate (1).

In the year 2015, a number of 1.6 million deaths have been caused by diabetes and its complications (according to the World Health Organization) (2), including the pathology of the diabetic foot.

In Romania the number of patients filed into records, in 2015, as having diabetes mellitus was of approximately 1 million people (according to the Federation of the Diabetics Associations of
Romania)(3), however, according to international data, for every diabetic patient there is at least one more undiagnosed (3-5).

The diabetic foot is a complex pathology which includes the totality of modifications occurred on the foot of a diabetic patient during the course of the disease (A.J. Boulton), namely: vascular, nervous, bone (bone and joints), muscular, skin modifications, in various stages of evolution.

A diabetic patient's foot has the risk of developing, during the course of the disease, various pathologic consequences: infections, ulcerations and/or disorders of the soft tissues, associated with complex neurologic modifications and various stages of peripheral vascular damage, thus there are two paths of evolution in the pathology of the diabetic foot: the neuropathic predominant diabetic foot and the 
arteriopathic predominant one (Fig. 1) $(6,7,8)$.

The survey aims to analyse the pathology of the arteriopathic predominant diabetic foot, as the patients having lesions which are specific to neuropathic damage represent a distinct chapter, being patients that most of the times have a favourable postsurgical outcome, due to the good blood supply.

For the arteriopathic predominant lesions, if there is no possibility to perform a surgical revascularisation, a major amputation often represents the therapeutic solution.

The vascular and nervous impairment depend on the evolution of the diabetic disease, the degree in which it is compensated, but also on the associated diseases of the patient. The diagnosis must be set early on, to allow the implementation of an adequate and as 'conservative' as possible treatment $(9,10,11)$.

The treatment of the diabetic foot complications is a mixed one: medical and surgical, to which complementary methods of treatment are added: plastic surgery, negative pressure therapy, hyperbaric oxygen therapy, neurolysis of the posterior tibial nerve, which improve the "success" rate for the diabetic foot wounds $(12,13)$.

The treatment is also a multimodal one and is involving: methods of redistributing the plantar pressure, surgical removal of the necrotic tissue, usage of special would dressings, antibiotherapy, revascularisation techniques, and in cases in which these cannot be implemented, amputations are performed (12-15).

The key point in treating these patients is the multidisciplinary approach, including: diabetologist, general surgeon, vascular surgeon, cardiologist, neurologist, nephrologist and ophthalmologist play an essential role. The role of the vascular surgeon is very important in assessing the opportunity of revascularisation and in attempting to limit the surgical intervention or to distalize the level of amputation $(12,16,17)$.

At the "I. Juvara" Surgery Clinic of the Dr. I. Cantacuzino Hospital, we have elaborated an prognostic-therapeutic index comprising a series of parameters that are easy to asses and

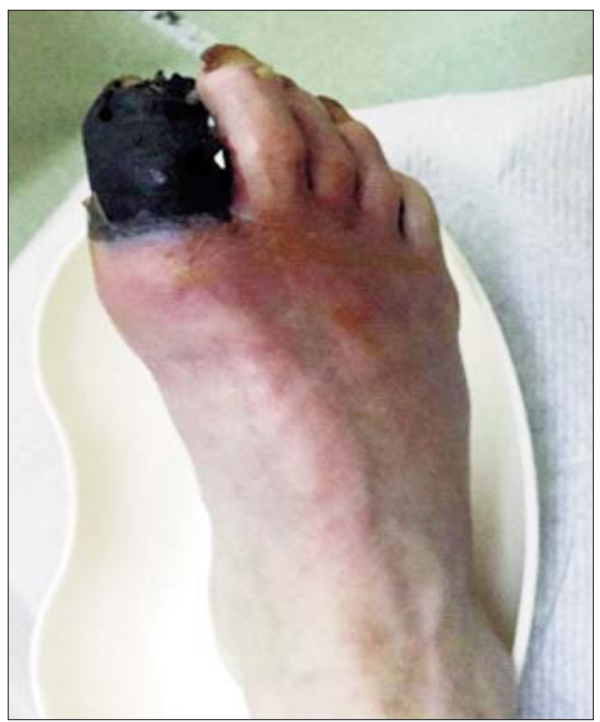

Figure 1. Arteriopathic Predominant Diabetic Foot

that guide the therapeutic attitude, especially in such centres in which the pathology of the diabetic foot is less well known (13).

The purpose of the article is to propose an update of the treatment algorithm for the arteriopathic diabetic foot pathology, thus achieving an early diagnosis and a treatment which is adapted to the type of lesion.

\section{Material and Method}

\section{Surveyed Population}

The retrospective survey comprised a group of 188 patients suffering from lesions belonging to the pathology of the arteriopathic predominant diabetic foot, which were admitted to the Surgery Clinic I of the "Dr. I. Cantacuzino" Clinical Hospital, between January 1st 2017 and December 31st 2017, during which all medical ethics regulations were observed.

In the Surgery Clinic of the Dr. I. Cantacuzino Hospital are admitted annually approximately 1.100 patients suffering from diabetic foot lesions. Of these, there was made a selection of eligible patients for the survey on the grounds of inclusion and exclusion criteria.

The criteria of inclusion of patients in the survey:

- Patients with lesions characteristic to the 
arteriopathic predominant diabetic foot: ischaemic gangrene of the toe/toes, wet gangrene of the toe/toes, suppurations localized at the foot level, on an arteriopathic ground (Fig. 2).

Criteria of exclusion:

- Patients with lesions characteristic for the neuropathic diabetic foot;

- Patients with arteriopathy, but nondiabetic;

- Patients with extensive suppurations, that extend at the calf $+/-$ thigh level;

- Patients which have not undergone surgery.

\section{Method}

In order to achieve the survey group there were taken clinical, paraclinical and surgery protocol data from the medical records of the Dr. I. Cantacuzino Clinical Hospital archives.

The descriptive statistics has required synthetizing, organizing and presenting the data written in the medical records with the purpose of offering a synthetic image of the analysed data. For the patients included in the survey, we have analysed the following data: demographic data (gender, age, background); clinical data upon admission (peripheral pulse, presence of the pain syndrome); paraclinical data related to biological parameters, anklebrachial index, but also imagistic modifications (arterial Doppler echography, arteriography); data related to the treatment of the lesions.

In order to organize the data obtained, there were used graphic representations, which have been statistically processed using the software programs MsOffice, Ms Excel and SPSS.

The vascular involvement diagnosis for these patients has been achieved by means of. pulse palpation, ankle-brachial index, arterial Doppler echography +/- arteriography.

The therapeutic approach of patients with arteriopathic predominant diabetic foot lesions requires two phases:

1. The Medical Treatment Phase that includes the metabolic rebalancing, correction of the acido-base balance, compensation of comorbidities (renal, cardiac, etc.). The vasodilator treatment is using injectable prostaglandins and needs to be given to these patients with the purpose of increasing the vascular support, necessary for the healing phase.

The antibiotic treatment is initially empiric, then at 72 hours, will be adapted to the antibiogram result. The flora specific to the diabetic foot is usually a polymicrobial flora, which includes: facultative germs Gram+, aerobes (Stafilococus aureus, Stafilococus

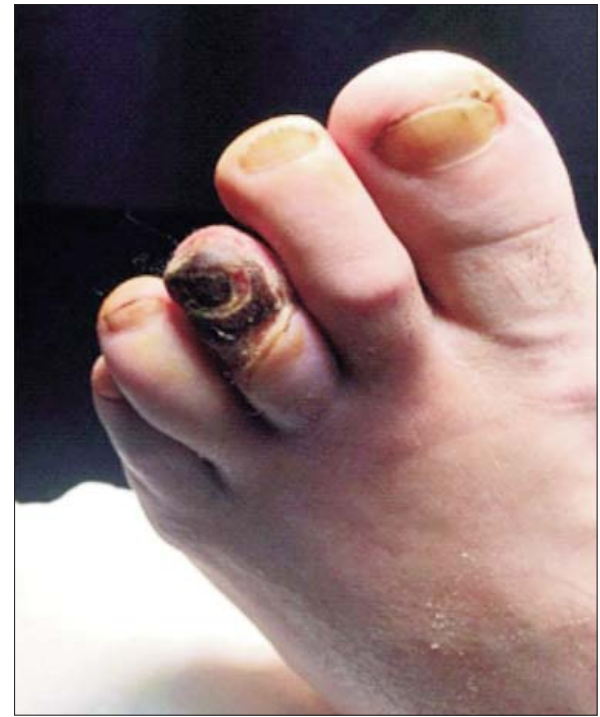

Figure 2. Ischaemic gangrene of the toe

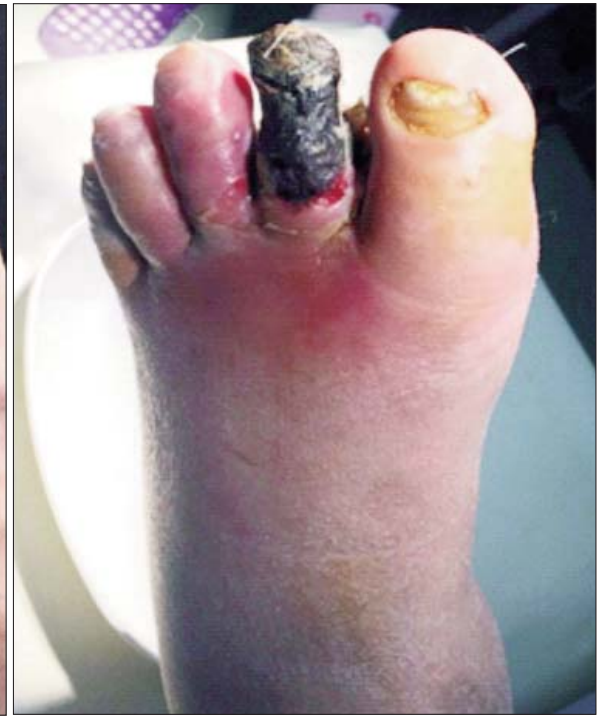

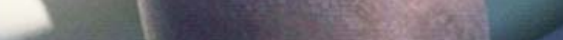


epidermidis, Streptococus haemolytic and nonhaemolytic), facultative bacilli Gram-, aerobes (Escherichia Colli, Klebsiela, Enterobacter, Pseudomonas), anaerobe germs (Clostridium perfringens, Bacteroides fragilis, Peptococus). The election antibiotic for moderate-severe lesions of the diabetic foot is ertapenem, however, other classes of drugs have proven to be effective: cephalosporins, quinolone, licosamine, other carbapenems $+/-$ metronidazole (for cases in which there is an association with an infection with anaerobe germs) (12-14).

2. The Surgical Treatment Phase, with two alternatives: (14-18):

a) surgical revascularisation is possible (desobstruction/by-pass), followed by surgical treatment when the lesions are limited(transmetatarsal amputation of the toe/toes, transmetatarsal amputation of the foot, amputation of the calf).

b) the vascular desobstruction is not possible,the only therapeutic solution is the surgical intervention (minor/ major amputation).

As far as the adjunctive treatment for the chronic wounds resulting from the diabetic foot surgery is concerned, for granulated wounds, without contamination, it is required to be covered using plastic surgery techniques: splited skin graft or flaps.The viability of the splited skin graft is clear in case of the neuropathic predominant diabetic foot, but for the arteriopathic one, when no revascularisation methods are used, healing can be difficult. Using the methods of covering the skin flaws resulted after diabetic foot surgery has lead not only to a significant reduction of the trailing lesions, but also to an improvement of the functional results (Fig. 3) (13,14).

Due to the considerable morbidity related to the spontaneous healing of the wounds following diabetic foot sugery, as well as the loss of functional mobility of these patients, the necessity of adjunctive methods of treatment is indisputable. The negative pressure therapy plays the role of enhancing granulation, of lowering the bacterial colonization and of bringing the edges of the wound closer together; the hyperbaric oxygen therapy is an auxiliary method consisting of placing the patient in a pressure resistant enclosure, that contains pure oxygen or air enriched with oxygen, at a pressure superior to that of the atmosphere, with the purpose of speeding up the healing (19).

\section{Results}

Of the analysed patients, $54.5 \%$ (102 patients) are of male gender, most of them from a rural origin, $64 \%$.

By studying the group of patients it was found that the most part belong to the age category $71-80$ years, namely $44 \%$, followed by the age group $61^{-70}$ years in which belong $32.4 \%$ of the patients.

As far as the treatment of compensation for the diabetes mellitus is concerned, $65.2 \%$ were taking oral antidiabetics, the rest were undergoing insulin therapy. All the patients included in the survey were suffering from diabetes mellitus of type II.

The clinical evaluation of the patient, aside from the general one, has also comprised the palpation of arterial pulse of the lower limb (femoral artery, popliteal artery, posterior tibial artery, pedal artery), thus $67.5 \%$ of the patients had palpable pulse on their femoral artery, $22.1 \%$ on the popliteal artery and $11 \%$ on the posterior tibial artery and pedal artery.

After analysing the group of patients from

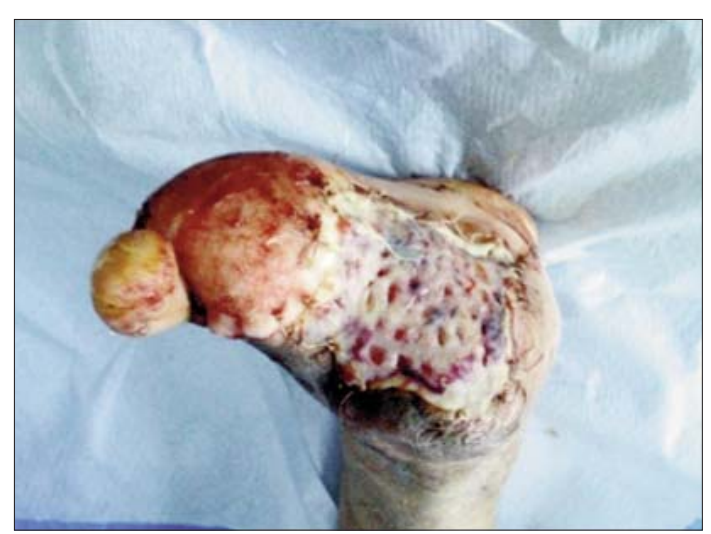

Figure 3. Splited skin graft 
the paraclinical point of view, $70.3 \%$ were showing leukocytosis upon admission to the hospital, 54.3\% were associating anaemia and $68.6 \%$ of patients had other comorbidities (untreated renal impairment, reactive thrombocytosis, high blood pressure and ischaemic cardiomyopathy, myocardial infarction and/or stroke in their medical history).

The calculus of the ankle-brachial index has shown values of less than 0.5 in $64.1 \%$ of cases, and the rest of the patients had an index ranging between 0.5 and 0.79 .

Of the 188 subjects in the investigated group, $27.7 \%$ (52 patients) already had an arteriographic investigation, 35.1\% (62 patients) were investigated by using only an inferior limb arterial Doppler echography, while the rest of the patients (74 patients) had benefited from vascular surgery evaluation after their surgery, the surgical intervention, as a first step, had been required because of the acute character of the lesion.
Finally, in case of 71 patients vascular desobstruction was attempted, 39 of them have benefited from favourable results as only in these cases revascularisation was possible. After applying the procedures of vascular surgery (desobstruction, by-pass)the following have resulted (Table 1, Fig. 4).

By applying the chi-square test, the value of 23.79 was obtained $(p<0,001)$.

All the patients have shown pain syndrome of the pelvic limb, in $55 \%$ of the cases the pain was moderate, and in the rest of the cases it was severe, associating the sloping position of the feet in order to diminish it.

The types of lesions present in the group of analysed patients are represented in the Table 2

All the patients have received medical treatment with vasodilatory substances and antibiotic treatment ( $68.1 \%$ with cephalosporins of generation II-III, $23.4 \%$ with quinolone, $8.5 \%$ with carbapenem)

Table 1. Distribution by surgery and revascularization

\begin{tabular}{lccccc}
\hline $\begin{array}{l}\text { Surgery / } \\
\text { Revascularisation }\end{array}$ & $\begin{array}{c}\text { Transmetatarsal amputation } \\
\text { of the toe/toes }\end{array}$ & $\begin{array}{c}\text { Transmetatarsal } \\
\text { amputation of the foot }\end{array}$ & $\begin{array}{c}\text { Major } \\
\text { amputation }\end{array}$ & TOTAL \\
\hline YES & 30 & 7 & 3 & 2 & 39 \\
\hline NO & 6 & 3 & 23 & 32 \\
\hline
\end{tabular}
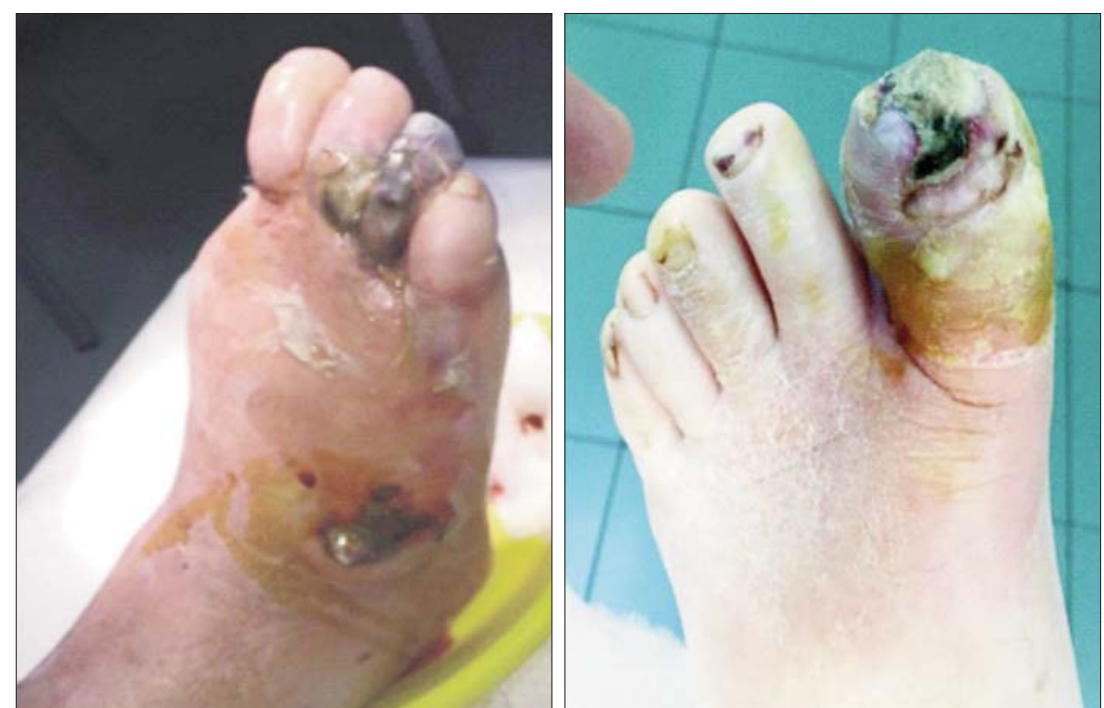

Figure 4. Wet gangrene toe + abscess of the foot 
Table 2. Distribution by the type of lesion

\begin{tabular}{lcccc}
\hline $\begin{array}{l}\text { Types of lesions / } \\
\text { patient no. }\end{array}$ & $\begin{array}{c}\text { Ischaemic gangrene } \\
\text { toe/toes }\end{array}$ & $\begin{array}{c}\text { wet gangrene } \\
\text { toe/toes }\end{array}$ & Abscess of the foot & TOTAL \\
\hline Number of patients & 76 & 96 & 16 & 188 \\
\hline$\%$ & 40.4 & 51.06 & 8.54 & \\
\hline
\end{tabular}

Table 3. Distribution by surgical intervention/type of lesion

\begin{tabular}{|c|c|c|c|c|c|}
\hline $\begin{array}{l}\text { Surgical intervention/ } \\
\text { type of lesion }\end{array}$ & $\begin{array}{c}\text { Transmetatarsal } \\
\text { amputation of } \\
\text { the toe/toes }\end{array}$ & $\begin{array}{c}\text { Transmetatarsal } \\
\text { amputation } \\
\text { of the foot }\end{array}$ & $\begin{array}{c}\text { Incision, } \\
\text { evacuation, } \\
\text { debridement }\end{array}$ & $\begin{array}{c}\text { Amputation } \\
\text { of } \\
\text { the calf }\end{array}$ & $\begin{array}{c}\text { Amputation } \\
\text { of } \\
\text { the thigh }\end{array}$ \\
\hline Ischaemic gangrene toe/toes (76 patients) & 48 & 7 & - & 5 & 16 \\
\hline Wet gangrene toe/toes (96 patients) & 65 & 11 & - & 7 & 13 \\
\hline Abscess of the Foot (16 patients) & 6 & 2 & 8 & - & - \\
\hline TOTAL & 119 & 20 & 8 & 12 & 29 \\
\hline
\end{tabular}

The results of the implemented surgical the diabetic foot is a complex entity, comprising treatment are represented in the Table 3 a large variety of lesions, for which the surgical(Fig. 5).

As a result of synthetizing the data coming from the patients' medical records and of the results supplied in this survey, we have elaborated the following treatment algorithm for patients suffering from arteriopathic predominant diabetic foot lesions (Fig. 6).

\section{Discussion}

By analysing the results obtained, the idea that therapeutic attitude is different, can be sus ${ }^{-}$ tained. Vascular and nervous impairment are present in all cases of patients with diabetic foot lesions evaluated in this survey, but in variable proportions and associates characteristic lesions for each category. The surgicaltherapeutic attitude is also related to the appearance of the lesion and the condition of the vascular status. Better surgical results are obtained in the cases of patients that underwent surgical revascularisation.

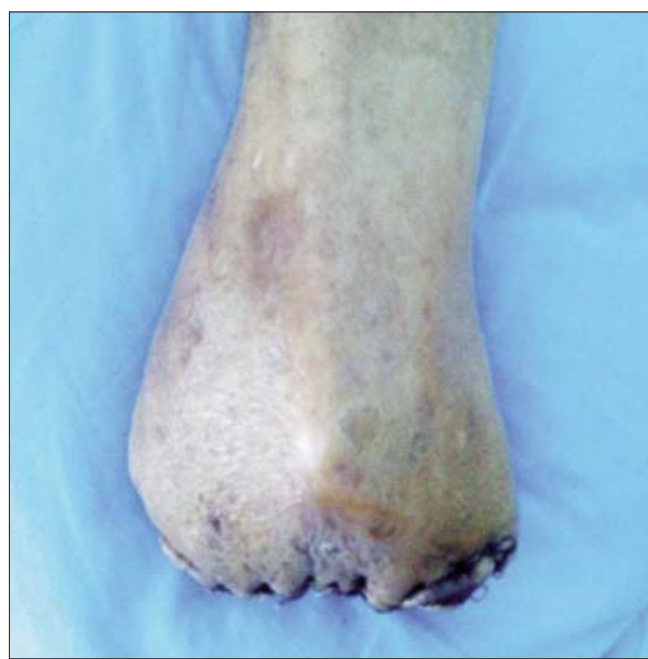

Figure 5. Amputation calf / thigh

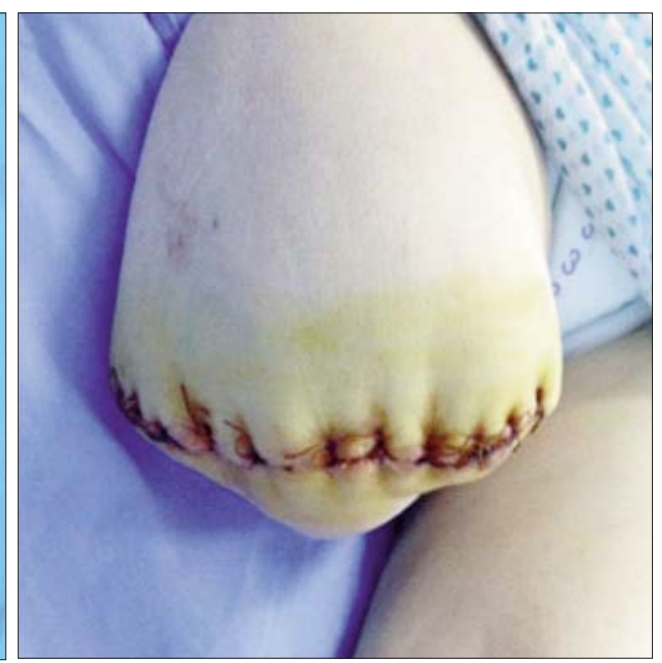




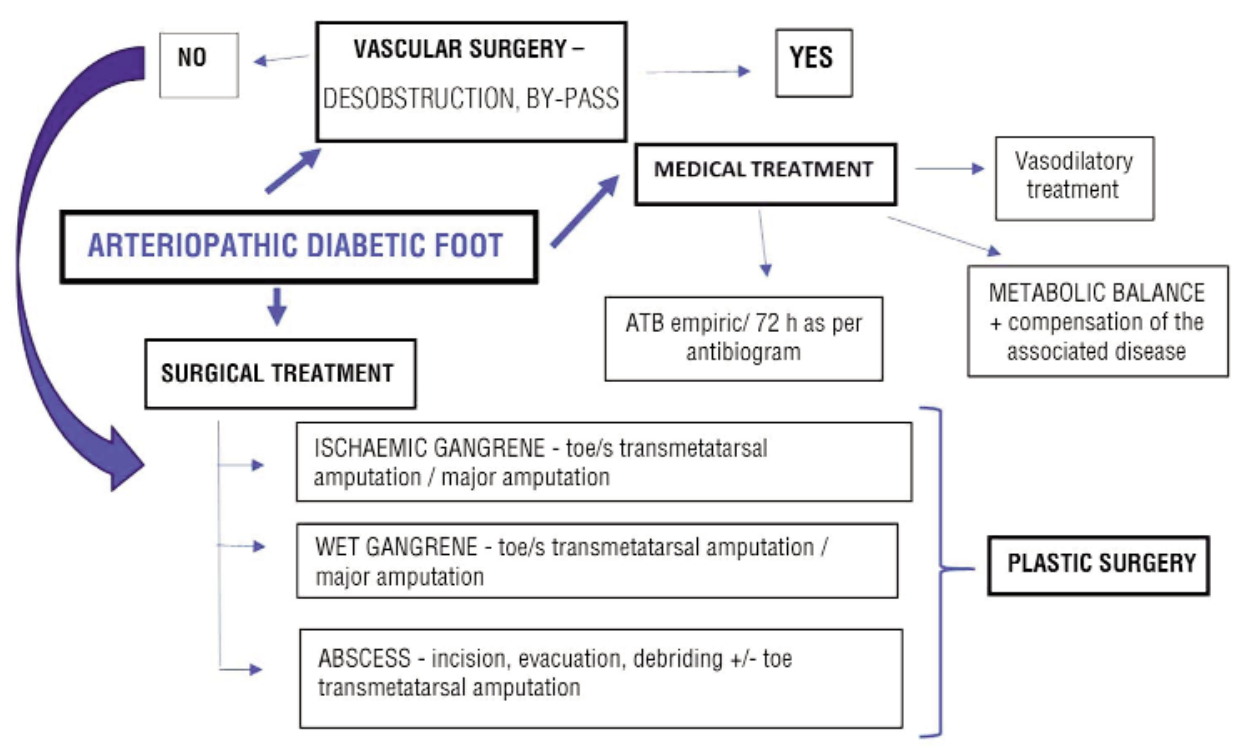

Figure 6. Algorithm of treatment for the arteriopathic predominant diabetic foot

Diabetic gangrene is the most severe complication of the diabetic foot and often make it necessary to practise a debilitating amputation.

Complications of diabetic foot require the association between the surgical treatment and the metabolic rebalancing, which makes it necessary for the surgeon to collaborate permanently with a metabolic physician,

The surgery of diabetic foot complications comprises a wide range of interventions, from incisions, debrides, transfalangeal and transmetataral amputations of toe/s or major amputations. Adjunctive treatments, such as: plastic surgery methods for the coverage of skin defects, negative pressure therapy and hyperbaric oxygenotherapy, both with the role of accelerating the process of wound granulation, represent methods that balance the evolution to healing $(20,21)$.

The multidisciplinary therapeutic approach is the solution for treating patients suffering from lesions of the diabetic foot, the vascular evaluation being the one that can provide a decrease in the number of debilitating interventions, an aspect also confirmed by the analysis of the group of patients included in the survey.

\section{Conclusions}

The treatment algorithm proposed by means of this survey represents a viable option, because it comprises all the aspects of a complete and complex therapeutic attitude for the arteriopathic predominant diabetic foot lesions. It is a multispecialty algorithm, in which the surgeon, the diabetologist, the plastic surgeon and the vascular surgeon play important roles in equal measure. The data belonging to the analysed patients have been placed at the grounds of elaborating this treatment algorithm for the surgical pathology of the diabetic foot, which will be reconfirmed by a future prospective analysis.

The current surgical approach to the pathology of the arteriopathic predominant diabetic foot has three main directions, namely: correct and complete evaluation of the lesion, revascularisation treatment, surgical treatment (minor/major amputations).

Every phase is manadatory in order for this algorithm to be complete, failure to abide by it may lead to errors in the treatment, in a sense of performing disproportionate surgery correlated with an inaccurate diagnosis. 


\section{Conflicts of Interest}

The authors declare no conflicts of interests.

\section{References}

1. WwW.idf.org

2. www.who.int

3. www.fadr.ro

4. Serban V. Romanian Treaty of Metabolic Diseases, vol.I and vo.I II, Ed. Brumar; 2010. p. 1-39.

5. American Diabetes Association. Therapy for Diabetes Mellitus and related disorders - fifth edition; 2012. p. 11-54.

6. Lichiardopol R. Diabetology Manual. Ed Ilex; 2011. p. 34-78

7. Joseph I. Wolfsdorf, MB. American Diabetes Association: Intensive diabetes management. BCh; 2009. p. 1-79.

8. López-Valverde ME, Aragón-Sánchez J, López-de-Andrés A, Guerrero-Cedeño V, Tejedor-Méndez R, Víquez-Molina G, et al. Perioperative and long-term all-cause mortality in patients with diabetes who underwent a lower extremity amputation. Diabetes Res Clin Pract. 2018;141:175-180.

9. Ferreira L, Carvalho A, Carvalho R. Short-term predictors of amputation in patients with diabetic foot ulcers. Diabetes Metab Syndr. 2018; 12(6):875-879.

10. Khalifa AA, Gueret G, Badra A, Gouny P. Diabetic critical ischemia of lower limbs: distal arterial revascularisation. Acta Chir Belg. 2009;109(3):321-6

11. Salvo NL, Walsh MD, Brewster LP. Promoting Limb Salvage through Multi-Disciplinary Care of the Diabetic Patient, Curr Treat Options Cardiovasc Med. 2017;19(7):55.

12. Brocco E, Ninkovic S, Marin M, Whisstock C, Bruseghin M,
Boschetti G, et al. Diabetic foot management: multidisciplinary approach for advanced lesion's rescue. J Cardiovasc Surg (Torino). 2018 May 29. doi: 10.23736/S0021-9509.18.10606-9

13. Patrascu T, Doran H. Particularities of Surgery in Diabetics. Editia a II-a. Ed. Niculescu; 2016. p. 13-61.

14. Bridges RM Jr, Deitch EA. Diabetic Foot Infections Pathophysiology and Treatment. Surg. Clincs of North Am. 1994; 74(3):537-55.

15. Reiber GE, Bowker JH, Pfeifer MA. Epidemiology of Foot Ulcers and Amputations in the Diabetic Foot. Ed. Mosby; 2001;2:13-31.

16. Hicks CW, Canner JK, Mathioudakis N, Sherman R, Malas MB, Abularrage CJ. The Society for Vascular Surgery Wound, Ischemia, and foot Infection (WIfl) classification independently predicts wound healing in diabetic foot ulcers. J Vasc Surg. 2018. pii: S0741-5214(18)30279-9.

17. Kolossváry E, Bánsághi Z, Szabó GV, Járai Z, Farkas K, Orv Hetil. Ischaemic origin of diabetic foot disease. Epidemiology, difficulties of diagnosis, options for prevention and revascularisation. 2017; 158(6):203-211.

18. Ndosi M, Wright-Hughes A, Brown S, Backhouse M, Lipsky BA, Bhogal M, et al. Prognosis of the infected diabetic foot ulcer: a 12month prospective observational study. Diabet Med. 2018; 35(1):78-88

19. Lone AM, Zaroo MI, Laway BA, Pala NA, Bashir SA, Rasool A, Vacuum-assisted closure versus conventional dressings in the management of diabetic foot ulcers: a prospective case-control study, Diabet Foot Ankle. 2014;5.

20. Huang YY, Lin CW, Yang HM, Hung SY, Chen IW. Survival and associated risk factors in patients with diabetes and amputations caused by infectious foot gangrene. J Foot Ankle Res. 2018;11:1.

21. Jang MY, Hong JP, Bordianu A, Suh HS. Using a Contradictory Approach to Treat a Wound Induced by Hematoma in a Patient with Antiphospholipid Antibody Syndrome Using Negative Pressure Wound Therapy. Int J Low Extrem Wounds. 2015; 14(3):303-6. 